Our American economist colleagues face demanding challenges in facilitating the transition to a market economy in the republics. Political scientists confront similar complexities in promoting the transition to democracy. The development of a viable and vibrant political science profession in the independent republics is one of the necessary, though hardly sufficient, guarantees that the goal will be achieved.

\section{References}

Dogan, Mattei and Robert Pahre. 1990. Creative Marginality: Innovation at the Intersections of Social Sciences. Boulder, CO: Westview Press.

Evgen'eva, A. P., ed. 1983. Slovar' russkogo iazyka $v$ chetyrekh tomakh [Dictionary of the Russian Language in Four Volumes].
Moscow: Russkii iazyk.

Glaveckas, Kestutis, ed. 1990. Rinkos ekonomika ir valstybinis reguliavimas [The Market Economy and Governmental Regulation]. Vilnius: Lietuvos Laisvosios Rinkos Institutas, Balticon.

Lijphart, Arend. 1984. Democracies: Patterns of Majoritarian and Consensus Government in Twenty-one Countries. New Haven: Yale University Press.

Malcolm, Neil. 1984. Soviet Political Scientists and American Politics. New York: St. Martin's.

Mills, Richard M. 1990. As Moscow Sees Us: American Politics and Society in the Soviet Mindset. New York: Oxford University Press.

Nechemias, Carol and Alfred Evans, Jr. 1991. "Political Science in the USSR," PS: Political Science \& Politics, 24, 4: 632-33.

Politologiia. Kurs lektsii. Uchebnoe posobie dlia vuzov. 1991. [Political Science. A Series of Lectures. A Textbook for Institutions of Higher Learning]. Moscow: Vysshaia shkola.
Shakhnazarov, Georgii Kh. and Fedor M. Burlatskii. 1984-85. "On the Development of Marxist-Leninist Political Science," Soviet Law and Government, 22, 3: 3-26. [Originally published in 1980.$]$

Taagepera, Rein. 1991. "Building Democracy in Estonia," PS: Political Science \& Politics, 24, 3: 478-81.

\begin{abstract}
About the Author
Richard M. Mills is a professor of political science at Fordham University, Bronx, NY. $\mathrm{He}$ is concerned with the challenges involved in deepning mutual understanding between Americans and former Soviets, a problem whose formative background he addressed in As Moscow Sees Us: American Politics and Society in the Soviet Mindset (Oxford, 1990). $\mathrm{He}$ is currently working on a study of the relationship of subfields in political science, especially American and comparative politics.
\end{abstract}

\title{
Political Dialogue with Some Women Leaders in Moscow and Leningrad
}

\author{
Wilma Rule, University of Nevada, Reno
}

$\mathbf{W}_{\text {ith the disintegration of the Soviet }}$ Union and the Communist Party, Russian women are awakening to the possibilities of an independent role in their nation's decisionmaking bodies. The road ahead is fraught with barriers posed by the electoral system and the lack of knowledge of alternatives, and by inexperience with independent party building and grass roots organizations. Also a nascent anti-feminist movement threatens Russian women's advances.

These are my impressions from two lectures and discussions with some women leaders in Moscow and Leningrad (now called St. Petersburg) about electing women to parliament in democratic countries, which occurred prior to the establishment of the Commonwealth of Independent States. The first session took place on March 2, 1991, at the Center for Gender Studies of the National Academy of Sciences in Moscow where I was invited to give a lecture. The second was a week later in St. Petersburg with friends of the Gender Center.
The women attending these sessions were young, most in their twenties to early forties, articulate teachers, researchers, writers, computer experts, doctors, and one factory worker. Among them were founders of new women's organizations.

The lecture was based on my studies of women's proportions in parliament and the contextual factors associated with their greater or lesser success in democratic countries, and personal interviews with women parliamentarians and leaders in the United States, Finland, Sweden, New Zealand, Israel and the Philippines.

From this research, I concluded that the best electoral arrangement for women's parliamentary election is the party list/proportional representation system which allows the voter to choose preferred candidates in large multimember districts, and which has no minimum proportion of votes for a party to be represented in the parliament.

Moreover, this electoral system is most efficacious when used in conjunction with a quota for the number of women placed on the party list. In Norway and throughout much of Europe, women's organizations within and without the parties directly influence the choice of about $40 \%$ women candidates who are then put in favorable positions on the parties' lists. That way the women elected must answer to women's groups and support women's programs. The women's groups-part of a wider women's movement-then mobilize the vote for the cooperating political parties.

The initial blank stares with which these statements were met revealed their unawareness of the electoral system which would most effectively help them achieve their goal for increased women's participation and influence. It was necessary, then, to detail how the party list/proportional representation system works in a multiparty system and how the parties' quotas advance women's nominations and their interests.

The mention of quotas for party nominations, however, was greeted with indignant cries of alarm. 
"Oh no, we don't like the quotathose Communist party women don't represent us!" was met with hearty agreement. An older woman forcefully stated, "Those women of the party usually don't have any children and don't care about women's problems."

This raised questions regarding an independent women's party, to which I noted the successes in Iceland and the failure in Israel as a result of lack of interest. Such parties have greater hopes of success in multiparty, proportional representation countries where new parties may gain seats in parliament with a minimum of votes. But in countries where only one person is elected from each constituency by majority or plurality vote-as in the United States, France, Great Britain, Canada, and New Zealandtwo major parties dominate and few if any minor party members are elected. Russia presently elects its parliament from single-member constituencies. A women's party has little chance of succeeding in such systems.

In parliamentary democracies with strong vertically unified parties and single-member districts, women can be nominated and elected without a women's party. For example, in Great Britain and New Zealand, the national labour parties have adopted a form of affirmative action to recruit more women to parliament. This accounts for those countries having greater proportions of women in parliament than the United States with its divided government, splintered parties, and high rates of incumbency. The United Stateswith about $6 \%$ women in the House of Representatives-ranked fourth lowest in women's parliamentary representation of 25 democracies (see Figure 1). Congressional campaigns are costly-personal ones requiring over $\$ 500,000$.

The Russian women were shocked by this information, First, they were amazed at what they considered to be an astronomical amount of money to run a congressional campaign (the equivalent of over ten million rubles). In Russia election expenses were paid by the Communist Party or the state (as is also true in many Western democracies). Furthermore, the group expressed disbelief and

FIGURE 1.

Percent Women in Parliament in 25 Democracies, 1985-87

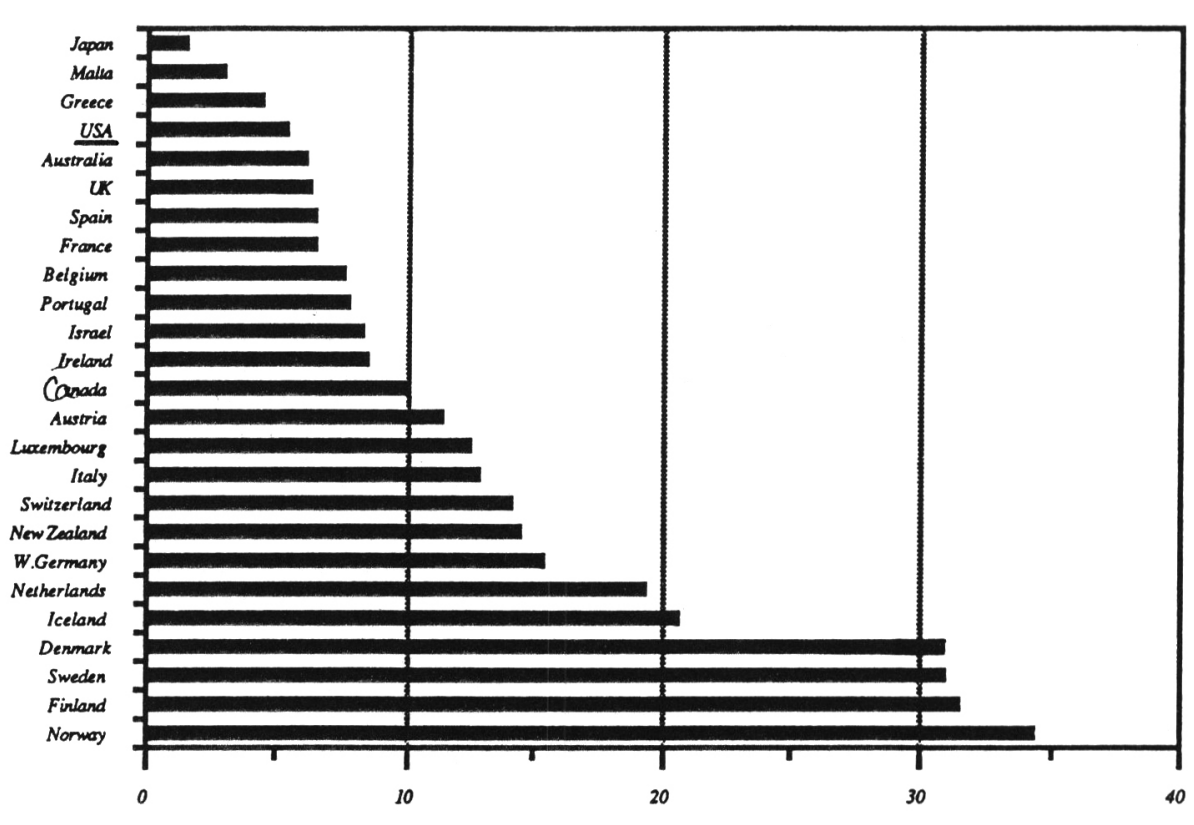

Source: International Centre for Parliamentary Documentation, Distribution of Seats Between Men and Women in National Assemblies (Geneva, Switzerland: 1987).

much curiosity in regard to women's underrepresentation in the United States. They previously had held the belief that countries with the most advanced economies had the greatest number of women in parliament.

Significant factors for women's election to national legislatures are large district magnitudes averaging about 12 representatives per district. Voters are more likely to give their votes to women when there are several people elected per district than when only one person can be chosen. This relationship can be seen clearly in the mixed system of Germany. Twice as many women are elected from the large multimember PR districts as are elected from the singlemember ones. Left and center parties have been most favorable to women's political recruitment.

Several social factors which are favorable for women's parliamentary opportunity exist in Russia. These include many women in the workforce. (A large majority of Russian women recently polled stated they would prefer working outside the home even if it were not a financial necessity.) Other propitious factors for women's political recruitment are full employment and a large proportion of women college graduates.

Lack of religious pluralismmonopolistic religion-operating as a political force is detrimental to women playing an equal role in elective government. This is the case in the Arab countries, Israel, Ireland and present-day Poland, and could occur in Russia. In Poland the church lobbies the new parliament for prohibition of abortion and birth control to get women back into a traditional role.

This attempt to prohibit birth control and abortion incited much discussion. "That is happening here. Today (March 2, 1991) Komsomolskaya Pravda, the official newspaper of the Young Communist League printed an article calling for the prohibition of abortions." This youth arm of the former Communist Party has tested the waters for antiabortion support. This followed renewed debate in recent years on "the women's question." It was resurrected with glasnost, openness and freedom to speak. Even former Soviet President Mikhail Gorbachev spoke of making it possible for "women to return to their purely 
womanly mission"' at home, bearing and raising children. With wider changes to a market economy and the likely unemployment, the end move may be an attempt to reserve the remaining jobs primarily for men.

There are several factors working against Russian women's election to parliament. Some of these, particularly inexperience with democratic political organizations, can be overcome. Others, such as single-member constituencies, unemployment, and antifeminist sentiment, may be more defeating to this cause. With the rapid changes which continue to occur, however, the window of opportunity seems to be open for women political leaders to take advantage of despite the many obstacles.
Note

*The author wishes to thank Carol Nechemias, Norma Noonan, David Schengold and Joseph Zimmerman for helpful comments, as well as Alma Cody for research assistance.

\section{Reference}

Rule, Wilma and Pippa Norris. Forthcoming. "Anglo and Minority Women's Underrepresentation in the Congress: Is the Electoral System the Culprit?"' in Wilma Rule and Joseph F. Zimmerman (eds.), U.S. Electoral Systems: Their Impact on Women and Minorities. Westport, CT: Greenwood.

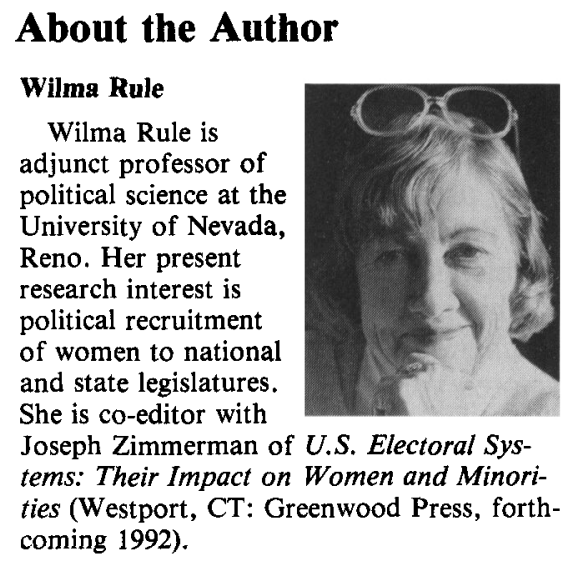

